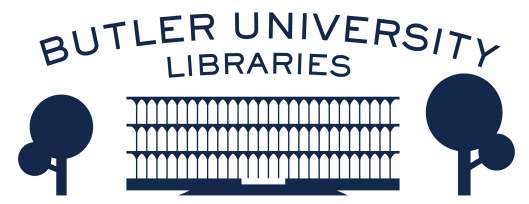

Journal of Hindu-Christian Studies

Volume 27

Article 7

November 2014

\title{
Violence against Christians in India: A Critical Discourse Analysis of Two Indian English Newspapers
}

Clemens Cavallin

University of Gothenburg

Julia Kuhlin

Lund University

Follow this and additional works at: https://digitalcommons.butler.edu/jhcs

Part of the History of Religions of Eastern Origins Commons

\section{Recommended Citation}

Cavallin, Clemens and Kuhlin, Julia (2014) "Violence against Christians in India: A Critical Discourse Analysis of Two Indian English Newspapers," Journal of Hindu-Christian Studies: Vol. 27, Article 7. Available at: https://doi.org/10.7825/2164-6279.1579

The Journal of Hindu-Christian Studies is a publication of the Society for Hindu-Christian Studies. The digital version is made available by Digital Commons @ Butler University. For questions about the Journal or the Society, please contact cbauman@butler.edu. For more information about Digital Commons @ Butler University, please contact digitalscholarship@butler.edu. 


\title{
Violence against Christians in India: A Critical Discourse Analysis of Two Indian English Newspapers
}

\author{
Clemens Cavallin \\ University of Gothenburg \\ and \\ Julia Kuhlin \\ Lund University
}

\section{INTRODUCTION}

During recent decades violence against Christians in India has increased significantly. In spite of this development the issue has received relatively little scholarly attention. ${ }^{1}$ Likewise, despite the massive transformation of the newspaper business, which has made contemporary India one of the largest newspaper markets in the world, ${ }^{2}$ only few studies have been done on the news coverage of religious minorities in India. In this article, we aim to contribute to both these areas of research. Using a critical discourse analysis, we examine the everyday representation of violence and harassment against Christians in the two largest English daily newspapers in India, Times of India and The Hindu. As pointed out by David A. Stout, news media is one of the main channels through which people gain knowledge about religion. ${ }^{3}$ They thus influence attitudes and ideas that may play a significant role for the intensity of conflicts and can facilitate or endanger the possibility of peaceful coexistence. We, therefore, consider the study

Clemens Cavallin is Associate Professor in History of Religions and Associate Head of the Department for Internationalization and Cooperation at the Department of Literature, History of Ideas, and Religion at the University of Gothenburg, Sweden. His research interests include Hinduism, ritual theory and Catholic studies. He has published two books: The Efficacy of Sacrifice (2002), which focuses on Vedic sacrifices, and Ritualization and Human Interiority (2013). He is presently working on a biography of the Canadian Catholic artist and author Michael O'Brien and is leading a project studying religious studies institutions in India.

Julia Kuhlin earned a Master's degree in the History of Religions at the Center for Theology and Religious Studies at Lund University, Sweden. Her major research interests are the Pentecostal movement in India and Hindu-Christian relations. Her master thesis Love Thy Hindu Neighbor as Thyself (2014) deals with North Indian Pentecostals' everyday interaction with the Hindu population and experiences of Hindu-Christian relations. 
of media representations to be an important tool to gain a better understanding of the underlying dynamics of violence against Christians in India.

\section{Background}

The $19^{\text {th }}$ century was a crucial transition period in the long history of Christianity in India. It was then that modernity began in earnest to transform South Asia, for example, through the railway and the introduction of western style higher education. In the intermingling of the old and the new, the stirrings of Hindu reform introduced by Ram Mohan Roy had by the end of the $19^{\text {th }}$ century through organizations like Arya Samaj, been partly transformed into a Hindu nationalist movement. Some Indians therefore considered, not surprisingly, conversion to Christianity as a threat to the nation and as a way for foreign powers to increase their control over India. ${ }^{4}$ Nevertheless, it was not until the $20^{\text {th }}$ century that the Hindutva (that is, 'hinduness') ideology was more thoroughly formulated. In 1920, Vinayal Damodar Savarkar published Hindutva, Who is a Hindu, often considered the foundational text of the movement, in which he argued that the conceptualization of an Indian national identity must rest on the ideology of Hindutva. ${ }^{5}$ In this way, one of the pillars of India's national identity becomes a common Hindu culture, to which all citizens of India should adhere. As a consequence, Christianity and Islam, religions of foreign origin, were considered to be threats to the Hindu rashtra. Indian Christians and Muslims were accordingly portrayed as being parts of the Hindu race that ought to be reintegrated into Hindu society.
Another competing perspective instead brought the two principles of the nation state and secularity together in a vision of India as a 'secular' state. This failed in part through the partition in 1947 and the creation of Pakistan as a Muslim state. However, the union, later republic, India, was founded as a democratic state with religious freedom as a basic principle. It needs to be pointed out, though, as does T. N. Madan in his article "Indian Secularism", that this does not entail a strict separation between state and religion (or church) but rather that "the state is expected to honor all religions, and not construct a wall of separation between them and itself." In such a vision all religions coexist with equal legitimacy within the framework of a tolerant democratic state.

In the shaping of the Constitution after Independence there was a need to channel the different views of the major religious groups into a common direction. Sebastian Kim argues that even if most nationalist leaders were adherents of a secular ideology, there was a bias in favor of the Hindu majority. ${ }^{7}$ Hence, the Constitution Assembly became the arena of a struggle between the Hindu majority and the minorities regarding the idea and practice of religious conversion. Christians argued that the right to change religion was a fundamental right for each individual. Those speaking against conversion, on the other hand, meant that it was an insult and that it undermined other religions, showing a lack of religious tolerance. Moreover, it was argued that conversions disturb the harmony of society and that it would be used for political ends. ${ }^{8}$ In the end, however, no law against conversion was written into the Constitution, and instead all 
citizens were ensured the right to "freely profess, practice and propagate their religion."

Nevertheless, the issue of conversion was not settled with the adoption of the Constitution. Since Independence, several states in India have passed so-called 'Freedom of Religion Bills,' which are meant to regulate conversions. The Bills differ slightly from each other, but in most cases entail that persons who want to change their religious affiliation should give prior notice of one month and that no person should attempt to convert anybody else by "force" or "allurement." In the Gujarat Bill, force refers to "force or a threat of injury of any kind including threat of divine displeasures or social ex-communication," and allurement "means offer of any temptation in the form of any gift or gratification, either in cash or kind; grant of any material benefit, either monetary or otherwise." ${ }^{10}$ It is tempting to argue, as Jennifer Coleman does, that these anticonversion laws are part of a Hindu nationalistic agenda bent on problematizing religious choice in India. ${ }^{11}$

Conversion, religious identity and the treatment of religious minorities have continued to be much disputed issues. Even if India for the most part has been under Congress rule since Independence, the influence of Hindu nationalism has been significant, and the recent election in 2014 was a real game changer. Through volunteer organizations like RSS and VHP, the movement has built up a large number of adherents all over India. Moreover, BJP - a Hindu nationalistic party, closely connected to RSS has manifested its power by being the only political party able to challenge the Congress party on a national level. Thomas Blom Hansen, author of The Saffron Wave, describes this development as that the Hindu nationalistic movement "has grown into the most powerful cluster of political and cultural organizations in the country."12 Some of these organizations have been involved in activities such as reconversion campaigns, rewriting of school books in accordance with a Hindu perspective of history, as well as in violent attacks on Christians and Muslims. ${ }^{13}$ And after BJP gained a majority of votes in the general election of 2014, commentators naturally wonder if the idea of Indian secularity will lose its superior position in relation to that of Hindutva. ${ }^{14}$ Nevertheless, one must recognize that secularism already was considered to be in crisis before the election. ${ }^{15}$

In terms of violence against Christians, Chad Bauman considers the end of the 1990s as a turning point towards a growing numbers of attacks. ${ }^{16}$ Between 1964 and 1996 the United Christians Forum of Human Rights estimates that there were 32 registered cases of communal violent attacks against Christians. However, in 1997 the number jumped to 15 in a single year, and as the first large-scale antiChristian riot broke out in Gujarat in 1998 the number grew dramatically to 90 . The following years the number of attacks continued to rise and reached the present level of around two hundred registered cases annually. Moreover, in 2007 and 2008, another major HinduChristian riot broke out, starting in Orissa, and spreading to several places around the country. ${ }^{17}$

Despite this development, the issue of recent anti-Christian attitudes and violence in India has received little attention. There are, nonetheless, three newly (2009-2011) published dissertations $^{18}$ that deal specifically with violence and harassment against Christians as 
well as numerous articles. ${ }^{19}$ In these studies, the focus is primarily on the task of understanding the socio-political origins of anti-Christian violence, and the impact of the Hindu nationalistic movement on the Christian community. The perspective of our study differs, as it deals with media representations and particularly with the construction of violence and harassment against Christians in daily newspapers.

\section{Theoretical Framework}

The present study is inspired by the approach of critical discourse analysis (CDA), which is a specific branch within the larger field of discourse analysis (DA), employed by inter alia Tuen A. van Dijk ${ }^{20}$ Norman Fairclough ${ }^{21}$ and Ruth Wodak. ${ }^{22}$ CDA is a form of qualitative text analysis concerned with the linguistic character of social processes and structures. ${ }^{23}$ It strives to uncover and expose how language is used to construct social identities, social relations and systems of knowledge that may strengthen inequalities. ${ }^{24}$ This aim rests on the assumption that discourse does not only reflect social structures and process, but also reproduces existing ones. Norman Fairclough formulates it as that a discourse is simultaneously socially constituted and socially constitutive. ${ }^{25}$ Accordingly, what distinguishes CDA from other discourse analysis approaches is that it seeks to reach beyond the description of discourse, and investigate in what way and why particular discourses are produced.

Fairclough has developed a threedimensional framework for critical discourse analysis of communicative events, in which he distinguishes between "text," "discourse practice" and "socio-cultural practice." ${ }^{26}$ Our study focuses on the text and its relation to the sociocultural practice. This means that the discourse practice (that is, text production, distribution and consumption) is not in focus. Obviously, this generates a gap, since we will neither consider the structural practices behind the production of the news, nor the decoding of the text by the consumer. ${ }^{27}$

The analysis schema that has been employed is partly based on a CDA questionnaire created by Peter Berglez for the analysis of newspaper articles. ${ }^{28}$ It consists of six different parts that elucidate both the macro-textual-level, the text's all-embracing characteristics (e.g. its thematic and schematic structure), and the micro-textual-level, that is, the details of discourse (e.g. wording, naming, sentence construction and implicit meanings).

\section{Material}

The data for the study comprises 20 articles published in the online versions of Times of India (11 articles) and The Hindu (9 articles), during the period from December 28, 2011 to February 12, 2012. The time frame was chosen as a random sample, and its rather limited scope means that the study cannot provide a comprehensive picture of how Christians are covered in media. Rather, it is a qualitative case study of the everyday representation of violence against Christians in two daily newspapers, and its results need to be explored in more extensive studies.

In the process of collection of material, two main criteria were applied. First, the lead story should be related to violence and harassment of Christians. Consequently, if an article only mentioned the subject, it was sifted out. However, the articles are not limited to reports of the actual violence, but they also contain 
stories of protests, arrests, and interviews with victims etc. The second main criterion was that it should be clear that the violence or harassment was directed towards Christians because they were Christians. This means that articles have been put aside in which Christians, among others, are described as subjected to violence or maltreatment. All articles that fulfill the two criteria during the mentioned period were collected.

\section{Results and Analysis}

The coverage of violence and harassment against Christians in the articles is characterized by the dominance of news relating to Christian protests against violent attacks committed against them. ${ }^{29}$ In half of the articles, this is the lead-story. As can be expected, this colors the discourse. The leadstories of the other ten articles are as follows: two discussions of newly published reports on violence against Christians in India; three articles accusing Christians of conversion by allurement and force; four short reports about victims of violence; and one report on an arrest of perpetrators. A general tendency within the articles is that Christians have a rather good access to discourse, which is not self-evident considering that earlier studies have shown that minorities tend to lack access to public discourse. ${ }^{30}$ However, this presence consists mainly of the voices of the Christian elite: leaders of Christian organizations, pastors and priests.

\section{Constructing Christians}

As the majority of the articles focus on Christians protesting in organized forms against violence committed against them, a representation of Christians as an energetic and well organized group emerges. This picture is reinforced by the other articles. For example, converted Christians who have been exposed to systematic marginalization in Manipur have set up a trust to improve their situation, ${ }^{31}$ and a "racial profiling of Christians" in Madhya Pradesh caused Christians to protest to the Chief Minister, who stopped the process. ${ }^{32}$ In other words, the journalists tend to narrate stories of Christians as a politically conscious and active group.

On the other hand, Christians are also depicted as a group that does not possess the means or influence to unaided change of its situation. Hence, this gives rise to a discourse of vulnerability. As one would expect, this is most explicitly expressed in the four short reports about particular victims of violence. These articles are characterized by wording such as "living in fear" 33 and "facing persecution." ${ }^{4}$

In addition to these two general representations of Christians, one can find two other contrasting discourses about Christians; one that is influenced by the Hindu nationalistic ideology and the other characterized by references to elements of the Indian form of secularism. The latter discourse arises chiefly in the self-identity construction by Christians and Christian organizations. The idiom 'Indian minority' is frequently used and connected to privileges such as the right to protection and freedom to practice their religion. The secularist discourse is utilized by Christians in three different ways. First, it is used as a springboard for Christians to claim their legal rights (primarily the right to protection). Second, it is used to construct the identity of the Christian community as an Indian minority that is an integrated part of Indian society. Lastly, the ideas are employed 
by Christian organizations to underline the identity of India as a secular and democratic country, a characteristic for such a country being that it takes care of its minorities.

The other discourse, which bears Hindu nationalistic underpinnings, constructs Christians as immoral and corrupt by accusing them of alluring and forcing non-Christians to convert to Christianity. In this discourse Christians are, due to the phenomenon of conversion, constructed as a growing threat within India. It has been highlighted by several scholars that a key element in the Hindutva discourse is the construction of religious minorities as an inner threat. ${ }^{35}$ This study reveals that such a discourse is also found in Times of India and The Hindu. Moreover, the finding of a tendency according to which Christians are pictured as immoral and corrupt corresponds with a general trend within news media to portray minorities negatively. ${ }^{36}$

Accusations that Christians are forcing or alluring people to convert are found in more than half of the articles. However, these accusations are part of quotations or the retelling of statements, and are not articulated by the journalists themselves. In other words, the journalists do not themselves connect Christians with these acts. On the other hand, they choose to include these comments and rarely state if there is any truth in the accusations. Moreover, they seldom criticize the statements or present a contrasting perspective. The readers are thus left to decide on their own whether there is any truth in the accusations. This tendency may be part of the journalistic tendency to report news in as neutral mode as possible. However, as the articles seldom include any contrasting viewpoint, the neutrality is tilted in one direction. The journalists as a result become knowingly or unwillingly active in reproducing the discourse of Christians as an immoral group and a growing threat within the country.

A central issue in most works concerning Christians of India is how the caste system affects the Christian community. This is hardly surprising in view of the fact that half of India's Christians come from a Dalit background and between $15-20 \%$ from an adivasi (tribal) background..$^{37}$ Furthermore, it has been argued that a major cause of violence against Christians is the fear of empowerment of low caste and tribal groups, which challenges the social-economic establishment. ${ }^{38}$

Nevertheless, the theme of caste or adivasi was only mentioned in four articles. In one, it was a key aspect of the story about a Dalit family living under threat. The other articles brought up caste in the following contexts (a) persecution against Christian adivasi villages has become more widespread; ${ }^{39}$ (b) a Christian family interrogated was identified as a "Hindu Chalti" (a caste classified as a Scheduled Caste) ${ }^{40}$ and (c) the Catholic Bishops' Conference of India criticized the government for delaying the response on issues concerning "Dalit Christians." ${ }^{41}$ The caste issue in the newspapers was consequently not a central theme - as it is within the academy - in the construction of violence against Christians. It is noteworthy, however, that in contrast to the general depiction in the articles of Christians as an energetic group, persons with Dalit or adivasi background are in all cases portrayed as victims. 


\section{Who's to Blame?}

In the articles there is a significant lack of information concerning the perpetrators behind the attacks, and only one article has an arrest as its lead-story. It is not unreasonable to expect there to be an interest on the part of the authorities to show that these criminals have been arrested, or at least that there is a public interest in knowing who stands behind the attacks. Nonetheless, it seems the topic is mostly avoided. In total there are only five attributes associated with the perpetrators; these are a) belonging to Hindu groups b) being Muslims c) being non-Christians d) being taxofficials e) being "gang members from Sarjapur." ${ }^{42}$ As these attributes are scattered and presented in very different contexts, it is not possible to frame a discourse concerning the perpetrators; they are at best described as unknown. ${ }^{43}$

Patricia spyer has made a similar observation (regarding unknown perpetrators) in her research on journalistic narrative strategies concerning conflicts and warfare in the Moluccas, Indonesia. ${ }^{44}$ In interviews, the journalists explain how they choose not to identify particular groups involved in violence in order to prevent the articles from fueling more hatred and violence. Spyer, however, argues that this minimalistic form of reporting on violence may have the opposite effect. Since there is no context or specific perpetrators named, violence in different circumstances begin to look alike and may lead to a growing fear since it potentially can occur anywhere. To draw any conclusions in this study concerning the reason behind the lack of information is not possible considering the restricted nature of the material. Reasons could be as varying as that the police do not dispense information, that the group identity of the perpetrators is self-evident for both the writer and the reader or that there is a power interest behind the shielding of the perpetrators. Irrespective, it may increase fear among Christians, as Spyer suggests, as well as function as a cover for the perpetrators since they become invisible to the public. The two newspapers are thus unwillingly or willingly part of a process shielding an unknown violent agent behind the attacks on Christians.

In contrast to the invisible perpetrators, there is a distinct discourse claiming that it is primarily the politicians who are to blame for the continuing attacks on Christians. This accusation is primarily presented by Christians and Christian organizations, but is also put forward by the journalists on their own initiative. The discourse is characterized by formulations such as: "Archbishop of Bangalore Nernard Moras also observes that the State Government had 'failed to safeguard the Christian minority""45 and "Mr. Saldanaha said that the Government of Karnataka should 'state whether it is capable of protecting each and every section of society' according to its Constitutional mandate." 46 The discourse of political responsibility rests on the presumption that the government and state governments are bound to protect minorities according to the Constitution, and when they are not taking this responsibility, they are guilty for the continuing attacks. Hence, in the majority of the articles, the focus moves from the perpetrators committing the assaults to a criticism of politicians for not protecting Christians properly.

These charges can be divided into two categories: accusations that stress the passivity of the state, and accusations that claim that the 
state is actively taking part in the persecution of Christians. The latter critique is not as frequent as the first and is uttered by representatives of Christian organizations or human rights organizations. For instance, the police are accused of destroying evidence from crime-scenes, ${ }^{47}$ BJP for being "inter-linked" with violent groups ${ }^{48}$ and tax officials for conducting illegal raids. ${ }^{49}$ The general secretary of the Catholic Bishops' Conference in India also claims that the anti-conversion laws that have been implemented by some states are "anti-constitutional." ${ }^{50}$ This severe critique of the anti-conversion laws is not unique in its kind, but has been raised by Christian, as well as Human Rights Organizations. For example, Christian Solidarity Worldwide stated in a report in 2006 that the laws impose severe restrictions on constitutional and international laws of freedom of religion. ${ }^{51}$ The report also declared that the implementation of anticonversion laws is worrying as it may be used in an ever-greater extent to justify attacks on Christians. More recently, A. G. Norrani, lawyer and formerly advocate in the Supreme Court of India, argues in his book Challenges to Civil Rights Guarantees in India that the laws run counter to Article 25 of the India Constitution, as well as threaten values of religious tolerance prized by the Constitution. ${ }^{52}$

The criticism that the politicians in power are passive draws mainly on three observations: (a) political silence in the face of violent attacks, (b) that the police and the judiciary are not acting "effectively" and (c) the delay in implementing laws against communal violence. In contrast to the critique of a state actively involved in persecution, the characterization of politicians as passive is at times strengthened by conclusions drawn by the journalist. For example, when a sharia court expelled two pastors from Kashmir, a journalist stated: "Although this court has no legal sanctity, political parties have remained silent." ${ }^{33}$

Commentaries from politicians appear only four times in the articles. They include (a) the interrogation of violated Christians by the Minority Commission (an agency created to protect minorities) $)^{54}$ (b) a comment by a tax official who performed a raid against a priest, saying he was only following orders from his headquarters $^{55}$ (c) a BJP politician, the vice president for a Minority Cell, accusing a pastor, who had been harassed, for conversions ${ }^{56}$ and (d) the denial by the Home Minister of Madhya Pradesh that any attacks against churches had occurred, despite a news report mentioning 15 attacks in the state during 2011. It is reported that: "when asked for comment on the case involving RSS and VHP supporters destroying Bibles and beating up a pastor besides looting the place, the home minister disconnected the phone." ${ }^{57}$ The above comments and actions by politicians strengthen the discourse of politicians as condoning the persecution of Christians.

It should be mentioned that there are four exceptions to this picture of compliant passivity, when a public authority is actually portrayed as doing something to counteract the violence. In three instances, the articles describe the police arresting suspects. In another article, it is stated that the chief Minister in Madhya Pradesh intervened on a "racial profiling of Christians" after protests. ${ }^{58}$

Within the period of this study, a persecution of Christians in Kashmir broke out. According to one article it was caused by a remark from a sharia court that accused three 
pastors of "luring the valley Muslims to Christianity." 59 In three articles, the Muslim religious establishment is depicted as nurturing and driving the persecution.

On the other hand, in other articles Muslims are depicted as protesting together with Christians against violent attacks, as well as being targets of attacks by Hindu groups. The construction of the relationship between Christians and Muslims is consequently multifaceted. The three articles from Kashmir bring complexity to the frequently one-sided depiction that behind the violence and harassment of Christians stand Hindu nationalist groups. At the same time, it must be recognized that Kashmir is a special case and has to be seen in a larger context that involves Pakistan.

\section{The Controversy over Conversion}

An issue that is much disputed in the articles, as well as being portrayed as the dominant motive for attacking Christians, is that of conversion. In fact, apart from conversion only one other motive is once mentioned, that is, Christians being targeted as Naxalites in Maharashtra. ${ }^{60}$ The reason behind anti-Christian violence in India is evidently not this one-sided, ${ }^{61}$ but in the everyday representation provided in these news articles a stereotypical story emerges of conversion as the cause for attacks.

In analyzing the articles, it became apparent that the word 'conversion' did not seem to refer to a person adopting a new religion, but something to which persons are subjected. It does not denote the idea of an autonomous individual choosing a religion; instead 'conversion' signifies the process in which persons are forced to leave their allegedly natural religious identity. Typical formulations are "two warned against conversion", "even prayer meetings are being accused to be attempts at conversion" ${ }^{\prime 3}$ and "leveling baseless allegation of conversion against pastor of..." ${ }^{64}$ Furthermore, Christians are frequently accused of forcing people or alluring them with, for example, bribes.

The notion of conversion seems to carry some implicit understandings, which are (a) that it is an immoral action, connected with allurement and force (b) that it is provoking strong emotional response (e.g. "A few weeks ago, the mere rumor that a few boys in a Ganderbal village had converted led to raids by..." ${ }^{65}$ and (c) that Christians are involved in these type of actions. The understanding of the phenomenon of conversion and the use of the term in news media thus seem to have been influenced by the Hindu nationalistic anticonversion discourse, as well as the discourse of anti-conversion laws.

Rita Manchanda has stressed that the Hindutva movement is increasingly gaining influence over discourse in mainline media, for instance by naturalizing terminologies and phrases. ${ }^{66}$ For example, Manchanda points out that "media played a vital role in the in the (sic) construction of a public discourse in which the four hundred-year-old Babri Masjid was converted into 'a disputed structure," hence, quietly being part of legitimizing the demolishment of the mosque in Ayodhya. ${ }^{67}$ That the word 'conversion' implicitly seems to mean 'forced conversion' or 'conversion by allurement' is most likely an example of the increased influence of Hindu nationalism on public discourse, as well as the anti-conversion laws. 
Significantly, there seem to be parts of the Muslim community in Kashmir that are using a similar rhetoric of conversion. The context of Kashmir is of course exceptional, as the region is living through one of the most serious conflicts confronting India during the last decades. The fact that the stories from Kashmir contain the strongest accusations concerning forced conversions may be an affect of the tensions in the region. A journalist writes: "even educated people this reporter spoke to believe sex, booze and money is the only reason why anyone would convert to Christianity."68 The same article finishes by stating that such an accusation is an "indictment they shall have to learn to live with."

It is noteworthy that the persons who are subjected to 'conversion activities' are rarely questioned about their experiences in the articles. When they are, they appear to be surprised that somebody considers their conversion to be forced and deny this. Only once does a person claim that he has been subjected to some kind of coercion. However, the story is portrayed as exaggerated by the journalist, who does not seem to believe it. A young Muslim boy states that he was forced to drink "swine blood" by Christians, and now is "progressively addicted to alcohol, women, money, drugs and the promise of weapons." ${ }^{69}$ The journalist finishes the story with the conclusion: "The story of a Class 10 student reads like a film script."

\section{Conclusion}

During the most recent decades violence and harassment against Christians in India have increased significantly. In contrast to HinduMuslim violence, which has been widely studied, violence against the Christian minority is relatively unexplored. As news media play a vital role in the shaping of public discourse concerning religious groups, investigating their reporting is of importance. In this article, we have focused on articles in two Indian newspapers (Times of India and The Hindu) during the first two months of 2012. Our analysis showed that the representation of Christians and the violence against them is multi-faceted. The result stands in contrast to Avinash Kumar's findings concerning the Muslim community, which showed that the portrayal of Muslims is predominantly negative. Instead the results of this study indicate a higher degree of complexity. ${ }^{70}$

The news articles do not present a univocal construction either of the social identity of Christians or of the violence committed against them. In others words, there is not one distinct and systematic 'neutral' language in the articles. Instead, the newspapers constitute an arena of struggle between different discourses. Most notable are the discourses influenced by ideas connected to forms of Indian secularism and ideas related to Hindu nationalism.

In regards to the latter, the findings support previous studies that have indicated that the influence over public discourse and mass media by the Hindutva movement is substantial. In our study, this is most evident concerning the discourse of conversion. The word is not used to refer to a person freely choosing a new religion, but to an immoral act where Christians are forcing or alluring people to abandon their 'natural' religious identity. This is in line with the understanding of religious identity in the Indian anti-conversion laws. It is worrying that both The Hindu and Times of India have adopted this discourse, as the accusation is dubious and can only 
strengthen the legitimacy of violence and harassment against Christians.

Moreover, the articles unanimously depict conversion as the reason behind attacks (only one other reason was once mentioned). This constitutes a simplification of the tensions between Hindus and Christians, so that only a stereotyped story of conversion as the cause of violence was offered by the newspapers.

The discourse influenced by the idea of India as a secular state caring equally for all religious groups constructs Christians as an Indian religious minority and is primarily put forward by the Christians themselves, who in the articles have a rather good access to discourse. It is, among other things, utilized as a springboard for Christians to claim their legal rights (primarily the right to protection). In stressing the identity of India as a secular and democratic country, the characteristics of such a country are highlighted, among other things being that it takes care of its minorities.

Lastly, the articles give practically no attention to the perpetrators, who become invisible in the news. Instead the claims are put forward that it is primarily the Indian political authorities who are to blame for the continuing attacks against Christians. The central and state governments are accused of being passive in the face of violence and the latter in some cases as being actively involved in the persecution.

The result of our study has its limitations and can only provide some features to be explored more fully in more extensive studies. Research incorporating a larger number of news media can give a more comprehensive picture of the representation of the Christian minority. Moreover, in present-day India, for example, Hindi-language newspapers have a prominent position and it is thus of importance to examine also their constructions of Christians, especially in terms of questions relating to violence and conversion.

\section{Notes}

${ }^{1}$ Chad Bauman, "Hindu-Christian Conflict in India: Globalization, Conversion, and the Coterminal Castes and Tribes," The Journal of Asian Studies 72, no. 3 (2013): 632-653. http://dx.doi.org/10.1017/S0021911813000569

2 Debashis Aikat, "India," in Encyclopedia of Journalism (Thousand Oaks, CA: SAGE Publications): 749-755, accessed, March 1, 2013, doi: http://dx.doi.org.ezproxy.ub.gu.se/10.4135 /9781412972048.n195.

${ }^{3}$ David A. Stout, Media and Religion: Foundations of an Emerging Field (New York and London: Routledge, 2012).

4 Christophe Jaffrelot, Hindu Nationalism: A Reader (Princeton: Princeton University Press, 2007). http://dx.doi.org/2027/mdp.390150707 68927

${ }^{5}$ Vinayak Damodar Savarkar, Hindutva, Who is a Hindu? (Veer Savarkar Prakashan, 1969). http://dx.doi.org/2027/mdp.39015026755465

${ }^{6}$ Triloki Nath Madan, "Indian Secularism," in Comparative Secularisms in a Global Age, ed. Linell E. Cady and Elizabeth Shakman Hurd (New York: Palgrave Macmillan, 2010), 189.

${ }^{7}$ Sebastian Kim, In Search of Identity (New Delhi: Oxford University Press, 2003). http://dx.doi.org/2027/mdp.39015056307542

${ }^{8} \mathrm{Kim}$, In Search for Identity, 38-40, 56.

${ }^{9}$ Indian Const. art. 25.

10 Gujarat Freedom of Religion Bill (2003), http://www.emw-d.de/fix/files/indienreligionsgesetz.pdf.

11 Jennifer Coleman, "Authoring (In)authenticity, Regulating Religious Tolerance: The Implications of Anti-Conversion 
Legislation for Indian Secularism," Cultural Dynamics 20, no. 3 (2008), 246. http://dx.doi.org/ 10.1177/0921374008096311.

12 Thomas Blom Hansen, The Saffron Wave: Democracy and Hindu Nationalism in Modern India (Princeton: Princeton University Press, 1999), 3. ${ }^{13}$ Robert E. Frykenberg, Christianity in India: from Beginnings to the Present (New York: Oxford University Press, 2010), 474-478.

14 For example, http://mediaindiagroup. wordpress.com/2014/05/18/analysis-of-the2014-indian-elections-a-vote-for-change-nothindutva, thinks that the vote was for change in government and not for a Hindutva politics. However, this requires that Prime Minister Modi keeps the lid on the more ideologically fervent groups within the party, something which can prove to be difficult.

15 See, for example, Rajeev Bhargava, ed., Secularism and its Critics (New Delhi: Oxford University Press, 2013) and Anuradha Dingwaney Needham and Rajeswari Sunder Rajan, eds., The Crisis of Secularism in India (Durham and London: Duke University Press, 2007.) http://dx.doi.org/2027/mdp.390150676 67827. For a field study see Ragini Sen, Wolfgang Wagner, and Caroline Howarth, Secularism and Religion in Multi-faith Societies: The Case of India (Cham: Springer, 2014) http://dx.doi.org/ 10.1007/978-3-319-01922-2. ${ }^{16}$ Bauman, "Hindu-Christian Conflict in India."

${ }^{17}$ Bauman, "Hindu-Christian Conflict in India," 633-634.

18 Varghese Appeliyil, "Violence against Christians of India in the First Decade of the Twenty-first Century" (doctoral dissertation, Bright Divinity School, Texas, 2009), UMI no. 3397155. Vedhamanickam C. T. PrabhuSingh, "Serving under the Saffron Shadow: Hindu
Nationalism, Violence and Christianity in Gujarat, India" (doctoral dissertation, Asbury Theological Seminary, Kentucky, 2008), UMI no. 3313405. Donald V. Zagardu, "India's Bharatiya Janate Party: Nationalism, Religious Zeal and Political Opportunism" (doctoral dissertation, St John's University, New York, 2011), UMI no. 3489103.

${ }^{19}$ See, e.g., Lancy Lobo, "Persecution of Indian Christians," Dialog: A Journal of Theology 41, no. 2 (2002): 114-122. http://dx.doi.org/10.1111/ 1540-6385.00107; Monica Melanchthon, "Persecution of Indian Christians" Dialog: A Journal of Theology 41, no. 2 (2002): 103-113. http://dx.doi.org/10.1111/1540-6385.00106;

Chad Bauman \& Tamara Leech, "Political Competition, Relative Deprivation, and Perceived Threat: A Research Note on AntiChristian Violence in India," Ethnic and Racial Studies 35, no. 12 (2012): 2195-2216. http://dx.doi.org/10.1080/01419870.2011.63155 8; and Bauman, "Hindu-Christian Conflict in India."

20 Tuen A. van Dijk, "Principles of Critical Discourse Analysis," Discourse \& Society, 4, no. 2 (1993): 249-283. http://dx.doi.org/10.1177/ 0957926593004002006 and Tuen A. van Dijk, "Discourse, Power and Access," in Texts and Practices: Readings in Critical Discourse Analysis, eds. Carmen Rosa Caldas-Coulthard \& Malcolm Coulthard (London: Routledge and Kegan Paul, 1996): 84-104.

${ }^{21}$ Norman Fairclough, Critical Discourse Analysis (London: Longman, 1992) and Norman Fairclough, Media Discourse (London: Edward Arnold, 1995).

${ }^{22}$ Ruth Wodak, Disorders of Discourse (London: Longman, 1996) http://dx.doi.org/2027/uc1. 32106012963960 and Ruth Wodak \& Michael 
Meyer, "Critical Discourse Analysis: History, Agenda, Theory and Methodology," in Methods of Critical Discourse Analysis, eds. Ruth Wodak \& Michael Meyer (London: Sage, 2009), 1-33. http://dx.doi.org/2027/mdp.39015053176841.

${ }^{23}$ Stefan Titscher, Michael Meyer, Ruth Wodak, \& Eva Vetter, Methods of Text and Discourse Analysis (London: Sage, 2000) http://dx.doi.org/10.4135/9780857024480.

${ }^{24}$ van Dijk, "Principles of Critical Discourse Analysis."

${ }^{25}$ Fairclough, Critical Discourse Analysis.

${ }^{26}$ Fairclough, Media Discourse.

${ }^{27}$ In fact, discourse practice is generally the most under-developed aspect of CDA. John E. Richardson, Analysing Newspapers: An Approach from Critical Discourse Analysis (Basingstoke, Hampshire: Palgrave Macmillan, 2007).

28 Peter Berglez, "Kritisk diskursanalys" in Metoder i kommunikationsvetenskap, eds. Mats Ekström \& Larsåke Larsson (Lund: Studentlitteratur, 2010): 265-288.

29 The Christian minority in India is a very diverse group, made up by approximately 150 denominations; see Lobo, "Persecution of Indian Christians." However, in news articles Christians are mostly only referred to as 'Christians', without clarifying the denominational belonging. We have chosen to follow this choice of wording. This is of course not unique for Christians, but applies with even more force to the notion of 'Hindus.'

${ }^{30}$ See e.g. Sari Pietikäinen, "Indigenous Identity in Print: Representations of the Sami in News Discourse," Discourse \& Society 14, no. 5 (2003): 581-609. http://dx.doi.org/10.1177/095792650 30145003; Avinash Kumar, "Mass-Media and Muslims in India: Representation or Subversion," Journal of Muslim Minority of Affairs
31, no. 1 (2011): $59-77$. http://dx.doi.org/10.1080/13602004.2011.55688 9; and Dijk, "Discourse, Power and Access." 31 "Trust Provides Respite to Meitei Christian Converts," Times of India, February 3, 2012, http://timesofindia.indiatimes.com/city/guwa hati/Trust-provides-respite-to-MeiteiChristian-converts/articleshow/11745805.cms. 32 "MP among Top Three in Church Attacks, Claims GCIC," Times of India, February 12, 2012, http://timesofindia.indiatimes.com/city/bhop al/MP-among-top-three-in-church-attacksclaims-GCIC/articleshow/11855332.cms. 33 "Dalit Christians living in Fear after Attack," The Hindu, January 29, 2012, www.thehindu.com/news/national/karnataka/ dalit-christians-living-in-fear-after-attack/ article2840643.ece.

34 "Trust Provides Respite to Meitei Christian Converts," Times of India.

${ }^{35}$ E.g. C. Jaffrelot, The Hindu Nationalist Movement and Indian politics: 1925 to the 1990s, (London: Hurst \& Company, 1996) http://dx.doi.org/2027/mdp.39015062087617 and John Zavos, "Conversion and the Assertive Margins: An Analysis of Hindu Nationalist Discourse and the Recent Attacks on Indian Christians," South Asia-Journal of South Asia Studies 24, no. 2 (2001): 73-90. http://dx.doi.org/ 10.1080/00856400108723451. ${ }^{36}$ Jessika ter Wal, "Conclusions" in Racism and Cultural Diversity in the Mass Media, ed. Jessika ter Wal (Vienna: European Monitoring Centre on Racism and Xenophobia, 2002); Simon Cottle, "Introduction. Media Research and Ethnic Minorities: Mapping the Field," in Ethnic Minorities and the Media, ed. Simon Cottle (Buckingham: Open University Press, 2000): 130. http://dx.doi.org/2027/uc1.3210601671519 
Violence against Christians in India 75

2; and Christopher Campbell, Race, Myth and the News (London: Sage, 1995) http://dx.doi.org/ 10.4135/9781483327211.

37 Rowena Robinson, Christians of India (New Delhi: Saga Publications, 2003). http://dx.doi.org/2027/mdp.39015061499565

38 Melanchthon, "Persecution of Indian Christians."

39 "Maharashtra among 10 states where Christians attacked," Times of India, January 12, 2012, http://timesofindia.indiatimes.com/city/ mumbai/Maharashtra-among-10-states-whereChristians-attacked/articleshow/11454649.cms. 40 "Minorities Commission Team Grills Victims of Communal Attack," The Hindu, January 7, 2012, www.thehindu.com/todays-paper/tpnational/tp-karnataka/minorities-commissionteam-grills-victims-of-communalattack/article2782141.ece.

41 "State Government failed to protect Christians," The Hindu, February 2, 2012, www.thehindu.com/todays-paper/tpnational/state-government-failed-to-protectchristians/article2852271.ece.

42 "Dalit Christians living in fear after attack," The Hindu.

${ }^{43} \mathrm{~A}$ common conclusion among scholars is that the increasing anti-Christian violence in India is to a large extent due to the growing influence of Hindu nationalist groups (e.g. Frykenberg, Christianity in India: from Beginnings to the Present; Chetan Bhatt, Hindu Nationalism: Origins, Ideologies and Modern Myths (New York: Berg, 2001) http://dx.doi.org/2027/mdp.39015054185 866; Jaffrelot, The Hindu Nationalist Movement and Indian politics; Appeliyil, "Violence against Christians of India;" Prabhu Singh, "Serving under the Saffron Shadow;" Zagardu, "India's Bharatiya Janate Party." However, this is not highlighted in the articles, not even by Christians.

${ }^{44}$ Patricia Spyer, "Media and Violence in the Age of Transparency: Journalistic Writing on War Torn Maluku," in Religion, Media and the Public Sphere, eds. Birgit Meyer \& Annelies Moors (Bloomington: Indiana University Press, 2006): 152-165. http://dx.doi.org/2027/mdp.390 15063656550

45 "State Government failed to protect Christians," The Hindu.

46 "File Cases against the Guilty in Church attack," The Hindu, January 3, 2012, http://www.thehindu.com/todays-paper/tpnational/tp-karnataka/file-cases-against-theguilty-in-church-attack/article2770476.ece. 47 "Earlier Communities Lived in Harmony," The Hindu, January 16, 2012, www.thehindu.com/news/cities/Mangalore/ea rlier-communities-lived-in-harmony/ article2805137.ece.

48 "State Government Failed to Protect Christians," The Hindu.

49 "Velim priest Raided, Locals Angry," Times of India, February 8, 2012, http://timesofindia.indiatimes.com/city/goa/ Velim-priest-raided-locals-angry/ articleshow/ 11800712.cms.

50 "State Government failed to protect Christians," The Hindu.

51 Christian Solidarity Worldwide (CSW), Briefing, India, Anti-Conversion Legislation: Summary of Concerns, November, 2006, http://www.cswusa.org/filerequest/1125.pdf

${ }^{52}$ Abdul Gafoor Noorani, ed., Challenges to Civil Rights Guarantees in India (New York: Oxford University Press, 2012). http://dx.doi.org/ 10.1093/acprof:oso/9780198074144.001.0001 
76 Clemens Cavallin and Julia Kuhlin

53 "Kashmir Zealots Push Christians into Valley of Fear," Times of India. January 23, 2012, http://timesofindia.indiatimes.com/india/Kash mir-zealots-push-Christians-into-valley-offear/articleshow/11595441.cms.

54 "Minorities Commission Team Grills Victims of Communal Attack," The Hindu.

55 "Velim Priest Raided, Locals Angry," Times of India.

56 "Monteiro Remark Condemned," The Hindu, January 25, 2012, www.thehindu.com/todayspaper/tp-national/tp-karnataka/monteiroremark-condemned/article2830483.ece. 57 "MP among Top Three in Church Attacks, Claims GCIC," Times of India.

${ }^{58}$ Ibid.

59 “'Fatwa' announced against Christian schools in Kashmir, 3 priests asked to leave valley," Times of India, January 19, 2012, http://timesofindia.indiatimes.com/india/Fatw a-announced-against-Christian-schools-in-

Kashmir-3-priests-asked-to-leavevalley/articleshow/11555784.cms.

60 "Maharashtra among 10 states where Christians attacked," Times of India.

${ }^{61}$ See e.g. Chad Bauman \& Leech, "Political Competition, Relative Deprivation, and Perceived Threat;" Chad Bauman, \& R. Young, "Minorities and the Politics of Conversion: With Special Attention to Indian Christianity," in Minority Studies, ed. Rowena Robinson (Delhi: Oxford University Press, 2012) and Melanchthon, "Persecution of Indian christians."

62 "Velim Priest Raided, Locals Angry," Times of India.

63 "MP among Top Three in Church Attacks, Claims GCIC," Times of India.

64 "Monteiro Remark Condemned," The Hindu.
65 "Kashmir Zealots Push Christians into Valley of Fear," Times of India.

66 Rita Manchanda, "Militarised Hindu Nationalism and the Mass Media: Shaping a Hindutva Public Discourse," South Asian Journal of South Asian Studies 25, no. 3 (2002): 301-320. http://dx.doi.org/ 10.1080/00856400208723504

${ }^{67}$ Manchanda, "Militarised Hindu Nationalism and the Mass Media," 320.

68 "Kashmir Zealots Push Christians into Valley of Fear," Times of India.

${ }^{69}$ Ibid.

${ }^{70}$ Kumar, "Mass-Media and Muslims in India. 